\title{
The Melanocortin Agonist AP214 Exerts Anti-Inflammatory and Proresolving Properties
}

\author{
Trinidad Montero-Melendez, ${ }^{*}$ Hetal B. Patel, ${ }^{*}$ \\ Michael Seed, ${ }^{*}$ Søren Nielsen, ${ }^{\dagger \neq}$ \\ Thomas E.N. Jonassen, ${ }^{\ddagger \S}$ and Mauro Perretti* \\ From The William Harvey Research Institute, ${ }^{*}$ Barts, and The \\ London School of Medicine, Queen Mary University of London, \\ London, United Kingdom; The Water and Salt Center, ${ }^{\dagger}$ University \\ of Aarbus, Aarbus, Denmark; Action Pharma A $/ S^{\ddagger}$ Aarbus, \\ Denmark; and the Department of Biomedical Sciences, \\ University of Copenhagen, Copenhagen, Denmark
}

Synthetic and natural melanocortin (MC) peptides afford inhibitory properties in inflammation and tissue injury, but characterization of receptor involvement is still elusive. We used the agonist AP214 to test MC-dependent anti-inflammatory effects. In zymosan peritonitis, treatment of mice with AP214 (400 to $800 \mu \mathrm{g} / \mathrm{kg}$ ) inhibited cell infiltration, an effect retained in $\mathrm{MC}$ receptor type 1 , or $\mathrm{MC}_{1}$, mutant mice but lost in $\mathrm{MC}_{3}$ null mice. In vitro, cytokine release from zymosan-stimulated macrophages was affected by AP214, with approximately $80 \%, 30 \%$, and $40 \%$ reduction in IL-1 $\beta$, tumor necrosis factor- $\alpha$, and IL-6, respectively. Inhibition of IL-1 $\beta$ release was retained in $\mathrm{MC}_{1}$ mutant cells but was lost in $\mathrm{MC}_{3}$ null cells. Furthermore, AP214 augmented uptake of zymosan particles and human apoptotic neutrophils by wild-type macrophages: this proresolving property was lost in $\mathrm{MC}_{3}$ null macrophages. AP214 displayed its pro-efferocytotic effect also in vivo. Finally, in a model of inflammatory arthritis, AP214 evoked significant reductions in the clinical score. These results indicate that AP214 elicits anti-inflammatory responses, with a preferential effect on IL-1 $\beta$ release. Furthermore, we describe for the first time a positive modulation of an MC agonist on the process of efferocytosis. In all cases, endogenous $M_{3}$ is the receptor that mediates these novel properties of AP214. These findings might clarify the tissue-protective properties of AP214 in clinical settings and may open further development for novel MC agonists. (Am J Pathol 2011, 179:259-269; DOI: 10.1016/j.ajpath.2011.03.042)
Inflammation is a localized defensive response of the body against pathogens and injury. Immune cells and soluble factors take part in this process to neutralize the injurious agent and initiate tissue repair to restore homeostasis. However, a loss of regulation of these mechanisms can prevent the final resolution of the inflammatory process, leading to a chronic pathologic status., ${ }^{1,2}$ Chronic inflammation is extremely relevant in today's modern medicine; it is now recognized that chronic inflammation contributes significantly to the pathogenesis of the most important diseases of industrialized societies, including atherosclerosis, cancer, and asthma. Given that chronic inflammation requires long-term pharmacologic treatments, new therapies with a lower degree of adverse effects are preferred. We and others have proposed exploitation of endogenous anti-inflammatory pathways to develop new drugs, reasoning that this pharmacologic strategy, mimicking the natural course of resolving inflammation, would represent a novel therapeutic approach. ${ }^{3-5}$ Among these natural anti-inflammatory and proresolving molecules are lipid mediators, such as lipoxins, resolvins, and protectins, as well as autacoids (eg, adenosine) and peptides, including annexin A1, galectin-1/9, and melanocortins (MCs).

The role of the $\mathrm{MC}$ system in inflammation has been known for more than 2 decades. ${ }^{6}$ Scientific and clinical interest in $\mathrm{MC}$ has increased in recent years with the identification of specific receptors and the development of new analogues with improved properties over those of the natural agonist $\alpha$-melanocyte-stimulating hormone $(\alpha-\mathrm{MSH})$. Natural peptides, especially corticotropin, $\alpha-\mathrm{MSH}$, and $\gamma-\mathrm{MSH}$, and synthetic analogues are anti-

Supported by a collaborative project between Action Pharma A/S and the William Harvey Research Foundation. This work forms part of the research themes contributing to the translational research portfolio of Barts and the London Cardiovascular Biomedical Research Unit, which is supported and funded by the National Institute for Health Research.

Accepted for publication March 21, 2011.

Disclosures: S.N. is cofounder and CEO of Action Pharma A/S (currently COO), and T.E.N.J. is cofounder of Action Pharma A/S.

Address reprint requests to Mauro Perretti, Ph.D., The William Harvey Research Institute, Barts and The London School of Medicine, Charterhouse Square, London EC1M 6BQ, United Kingdom. E-mail: m.perretti@qmul.ac.uk. 
inflammatory in several in vivo models. Getting et al reported the anti-inflammatory effects of the analogue D-Trp ${ }^{8}-\gamma-\mathrm{MSH}$ in a model of crystal-induced inflammation $^{7}$ and, more recently, in an model of allergic inflammation. ${ }^{8}$ The same compound was also active in a model of ischemia-reperfusion injury ${ }^{9}$ and in inflammatory arthritis. ${ }^{10}$ The $\alpha$-MSH-derived C-terminal tripeptide KPV is anti-inflammatory in crystal-induced peritonitis ${ }^{11}$ and in two models of inflammatory bowel disease. ${ }^{12}$ New therapeutic strategies based on this line of research have also explored $\alpha$-MSH gene therapy in a model of thioacetamide-induced hepatic fibrosis, ${ }^{13}$ affording tissue protection, and the oral administration of recombinant Lactobacillus casei, which secretes $\alpha$-MSH, which reduced body weight loss, survival, clinical score, and myeloperoxidase (MPO) activity in a model of ulcerative colitis. ${ }^{14}$

In in vitro settings, $\mathrm{MC}$ agonists display anticytokine effects on macrophages ${ }^{15}$ and can induce the development of cytotoxic CD8 ${ }^{+} \mathrm{T}_{\text {cells }}{ }^{16}$ and $\mathrm{CD}_{2} 5^{+} \mathrm{CD} 4^{+}$regulatory $\mathrm{T}$ cells. ${ }^{17}$ These anti-inflammatory effects are attributed to the interaction of $\mathrm{MC}$ peptides with the $\mathrm{MC}$ receptors $\mathrm{MC}_{1}$ and $\mathrm{MC}_{3}$, which are expressed in several immune cells and tissues. ${ }^{6}$ In fact, of the five MC receptors cloned, ${ }^{18}$ these two have been associated with the anti-inflammatory and tissue protective properties of MC peptides. In some experimental settings, $\alpha$-MSH seems to control peripheral inflammation through activation of $\mathrm{MC}$ receptors in the brain. ${ }^{6}$ In any case, the main issue of which real MC receptor to target for anti-inflammatory drug discovery programs is still unsolved, possibly indicating the existence of regional and disease-specific expression patterns.

In the present study, we investigated the anti-inflammatory properties of AP214, an $\alpha$-MSH analogue with the addition of a long $\mathrm{N}$-terminal lysine sequence yielding high affinity for $\mathrm{MC}_{1}$ and $\mathrm{MC}_{3}$ over $\mathrm{MC}_{5}$. AP214 displays tissue-protective effects against renal postreperfusion injury, ${ }^{19,20}$ but the mechanisms behind these tissue-protective actions have not been elucidated. Besides studying the anti-inflammatory and anticytokine effects of AP214 in mice and in cells bearing inactive $\mathrm{MC}_{1}$ or nullified for $\mathrm{MC}_{3}$, we describe the proresolving nature of AP214 on the process of phagocytosis and efferocytosis, a new aspect of MC-based therapy.

\section{Materials and Methods}

\section{Animals}

Male mice (age, 7 to 8 weeks; body weight, $\sim 30 \mathrm{~g}$ ) were maintained on a standard chow pellet diet and had free access to water, with a 12-hour light-dark cycle. C57BL/6J wild-type (WT) mice were purchased from Charles River Laboratories (Wilmington, $\mathrm{MA}$ ). $\mathrm{MC}_{1}{ }^{-1-}$ mice (bearing an inactive mutant $\left.\mathrm{MC}_{1}\right)^{21}$ and $\mathrm{MC}_{3}{ }^{-1-}$ mice ${ }^{22}$ were kindly donated by Dr. Nancy Levin (Trega Biosciences, San Diego, CA) and Dr. Howard Y. Chen (Merck, Whitehouse Station, NJ), respectively. All the animal studies were approved by and performed under the guidelines of the Ethical Committee for the Use of Ani- mals, Barts and The London School of Medicine and Home Office regulations (Guidance on the Operation of Animals, Scientific Procedures Act, 1986).

\section{AP214 Synthesis and Validation}

AP214 has been produced by standard solid phase peptide synthesis by Bachem AG (Bubendorf, Switzerland). This $\mathrm{MC}$ agonist displays higher affinity for human $\mathrm{MC}_{1}$ and $\mathrm{MC}_{3}$ over $\mathrm{MC}_{5}$, for instance, with inhibition constants calculated from binding assays performed with transfected cells of 2.9 and $1.9 \mathrm{nmol} / \mathrm{L}$, respectively. ${ }^{19,20}$ Herein, we quantify the ability of AP214 to activate the five $M C$ receptors.

Murine B16-F1 cells that express $\mathrm{MC}_{1}$, Cloudman $\mathrm{M} 3$ cells that express $\mathrm{MC}_{2}$, and $\mathrm{CHO}$ cells that express $\mathrm{MC}_{3}$, $\mathrm{MC}_{4}$, or $\mathrm{MC}_{5}$ were used to determine agonistic activity, testing AP214 in a concentration range of $10^{-10}$ to $10^{-4}$ $\mathrm{mol} / \mathrm{L}$. Incubation periods were optimized in preliminary experiments, selecting 10 minutes at $22^{\circ} \mathrm{C}$ for $\mathrm{MC}_{1}$ and $\mathrm{MC}_{2}$ transfected cells, 30 minutes at $27^{\circ} \mathrm{C}$ for $\mathrm{MC}_{3}$ and $\mathrm{MC}_{4}$ cells, and 30 minutes at $22^{\circ} \mathrm{C}$ for $\mathrm{MC}_{5}$ cells. Accumulation of CAMP was expressed as a percentage of the maximal control specific agonist response [(measured specific response/control specific agonist response) $\times$ 100]. [Nle4, D-Phe7]- $\alpha$-MSH was used as control specific agonist for $\mathrm{MC}_{1}, \mathrm{MC}_{3}$, and $\mathrm{MC}_{4}$ cells; corticotropin was used as control specific agonist for $\mathrm{MC}_{2}$ transfected cells; and $\alpha$-MSH was used as control specific agonist for $\mathrm{MC}_{5}$ cells. All the experiments were performed in triplicate.

$\mathrm{EC}_{50}$ values were determined by nonlinear regression analysis of the concentration-response curves generated with mean replicate values using Hill equation curve fitting as follows: $Y=D+[(A-D) /(1+[C / C 50] n H)]$, where $Y$ indicates specific response; $D$, minimum specific response; $A$, maximum specific response; $C$, compound concentration; $\mathrm{C} 50, \mathrm{EC}_{50}$; and $\mathrm{nH}$, slope factor.

Preliminary pharmacokinetics analyses in the rat reveal that AP214 (1 mg/kg given i.v.) displays a short half-life ( $\sim 15$ minutes) with a relative large volume of distribution, suggesting distribution to tissues and/or extravascular sites. Indications for lower clearance in renal and hepatic blood flow would be consequent to restricted clearance; hence, the compound is likely bound to receptors and/or plasma proteins in a tight manner.

\section{Models of Inflammation}

\section{Zymosan-Induced Peritonitis}

Peritonitis was induced by the injection of $1 \mathrm{mg}$ of zymosan (Zymosan A; Sigma-Aldrich, Poole, UK) i.p. in $0.5 \mathrm{~mL}$ of sterile PBS. Animals (six per group) were pretreated with compounds or vehicle (PBS) administered i.p. 30 minutes before zymosan injection. AP214 initially was studied with a large dose range (100-1600 $\mu \mathrm{g} / \mathrm{kg}$ ), and doses of 400 and $800 \mu \mathrm{g} / \mathrm{kg}$ were chosen for the experiments reported herein. Four hours later, mice were sacrificed by $\mathrm{CO}_{2}$ exposure, and the peritoneal cavities were washed with $4 \mathrm{~mL}$ of ice-cold PBS containing 3 
$\mathrm{mmol} / \mathrm{L}$ EDTA and $25 \mathrm{U} / \mathrm{mL}$ of heparin. Aliquots of lavage fluids $(100 \mu \mathrm{L})$ were stained with Turk's solution $(0.01 \%$ crystal violet in $3 \%$ acetic acid), and cells were counted using a Neubauer hemocytometer or were stained with fluorescein isothiocyanate-conjugated monoclonal antibody for Ly-6G/Gr1 ${ }^{+}$(clone RB6-8C5; $10 \mu \mathrm{g} / \mathrm{mL}$ final concentration) before flow cytometry using a BD FACSCalibur platform (BD Biosciences, Franklin Lakes, NJ). Isotype control fluorescein isothiocyanate rat lgG2b (clone eBR2a) and blocking antibody anti-mouse $\mathrm{CD} 16 / 32$ were used. All the antibodies were purchased from eBioscience (Hatfield, UK).

\section{K/BxN Serum Transfer Arthritis Model}

Arthritis was induced by the i.p. injection of mice with $100 \mu \mathrm{L}$ of serum from K/BxN arthritic mice at day 0 (a gift from Dr. Mohini Gray, University of Edinburgh, Edinburgh, Scotland). Mice $(n=6)$ were treated i.p. with compounds or vehicle (PBS) twice daily for 10 days. The development of the disease was monitored for 2 weeks by assessing paw volume using a plethysmometer (Ugo Basile, Comerio, Italy), body weight, disease incidence, and disease score (1 point was given for each digit or wrist joint that presented with erythema plus swelling; a maximum of 22 points could be scored per animal). ${ }^{10}$

\section{Cell Preparations}

\section{Primary Peritoneal Macrophages in Vitro}

Mice were injected with $1 \mathrm{~mL}$ of $2 \%$ Bio-Gel (Bio-Rad, Hemel Hempstead, UK) i.p., and 4 days later cells were collected by peritoneal lavage using $4 \mathrm{~mL}$ of $3 \mathrm{mmol} / \mathrm{L}$ EDTA in PBS and were plated in 24-well plates at a density of $0.5 \times 10^{6}$ cells per well in RPMl 1640 medium containing $10 \%$ fetal calf serum and $50 \mathrm{mg} / \mathrm{mL}$ of gentamicin. After 2 hours of incubation, nonadherent cells were removed, and $1 \%$ fetal calf serum medium containing compounds or vehicle was added for 30 minutes before stimulation with $25 \mu \mathrm{g} / \mathrm{mL}$ of zymosan. Supernatants [for enzyme-linked immunosorbent assay (ELISA) measurements] or cells (stored in RLT buffer for RNA extraction) were collected after 6 hours and were kept frozen at $-80^{\circ} \mathrm{C}$ until use.

\section{Neutrophil Isolation from Human Blood}

Experiments using healthy volunteers were approved by the local research ethics committee (P/OO/ 029 East London and The City Local Research Ethics Committee 1). Informed written consent was provided according to the Declaration of Helsinki. Blood was collected into $3.2 \%$ sodium citrate and was diluted $1: 1$ in RPMI 1640 medium before separation through a double-density gradient using Histopaque 10771 and 11191 (Sigma-Aldrich). After polymorphonuclear cell isolation and washing, contaminating erythrocytes were removed by hypotonic lysis. After a final washing step with RPMI 1640 medium, cells were resuspended at a concentration of $4 \times 10^{6}$ cells $/ \mathrm{mL}$ in $10 \%$ fetal calf serum containing medium and were incubated overnight at $37^{\circ} \mathrm{C}, 5 \% \mathrm{CO}_{2}$, to allow neutrophils to undergo spontaneous apoptosis (range, $40 \%$ to $60 \%$ ).

\section{Phagocytosis Assays}

\section{Zymosan Phagocytosis}

Phagocytosis of zymosan particles was studied in BioGel-elicited murine macrophages. Macrophages were plated at a density of $1.5 \times 10^{6}$ cells per well in 48-well plates in a final volume of $0.5 \mathrm{~mL}$. After pretreatment for 30 minutes with $10 \mathrm{nmol} / \mathrm{L}$ AP214 (in 1\% fetal calf serum medium) or vehicle, zymosan was added at an approximate ratio of 1:5 (macrophage/zymosan, as established in preliminary analyses). At the reported time points, cells were washed three times with PBS to remove free particles and were analyzed by light microscopy, with three random fields per well ( $n=3$ wells per treatment) and counting an average of 250 cells per condition per time point.

\section{Apoptotic Neutrophils}

For in vitro studies, a plate-based MPO assay was performed as previously described. ${ }^{23}$ Bio-Gel-elicited peritoneal macrophages were collected and plated at a density of $0.5 \times 10^{6}$ cells per well in 24-well plates. Cells were pretreated with AP214 or vehicle for 30 minutes in a final volume of $0.5 \mathrm{~mL}$; apoptotic neutrophils were then added at a ratio of 1:2 (macrophage/neutrophil). After 1-hour incubation, cells were washed with cold PBS and were fixed for 30 minutes in $2.5 \%$ glutaraldehyde. Cells were then rinsed with PBS, and the MPO assay was performed by adding $0.1 \mathrm{mg} / \mathrm{mL}$ of dimethoxybenzidine (Sigma-Aldrich) and $0.03 \%(\mathrm{v} / \mathrm{v})$ hydrogen peroxide. Cells were washed with PBS 1 hour later and were analyzed by light microscopy, with three random fields being acquired per well ( $n=3$ wells per treatment). More than 400 cells were counted per treatment point.

To study in vivo phagocytosis by resident peritoneal macrophages, mice were injected i.p. with apoptotic CFSE-labeled human neutrophils $\left(3 \times 10^{6}\right.$ cells per mouse) 30 minutes after i.p. dosage with AP214 (400 or $800 \mu \mathrm{g} / \mathrm{kg}$ ) or vehicle (PBS, $250 \mu \mathrm{L}$ ). Neutrophils were stained by incubation in CFSE ( $5 \mu \mathrm{mol} / \mathrm{L}$ in PBS) for 5 minutes. Mice were sacrificed 30 minutes later, and peritoneal cells were collected by lavage with $3 \mathrm{~mL}$ of icecold PBS containing $3 \mathrm{mmol} / \mathrm{L}$ EDTA. Phagocytosis was assessed by flow cytometry as previously described ${ }^{24}$ using a BD FACSCalibur platform.

\section{Biochemical and Molecular Analyses}

\section{ELISA Determinations and Enzyme Immunoassay}

Levels of IL- $1 \beta$, tumor necrosis factor- $\alpha$ (TNF- $\alpha$ ), and IL- 6 were quantified in the supernatants from cultured macrophages according to the manufacturer's instructions using ELISA Ready-SET-Go! (eBioscience) and a 1:5 dilution for IL-1 $\beta$ and a 1:10 dilution for TNF- $\alpha$ and IL-6. Intracellular CAMP was measured in macrophages treated for $30 \mathrm{~min}$ - 
Table 1. Determination of the Functional Variables for AP214 Activation of Human MC Receptors

\begin{tabular}{|c|c|c|c|c|c|c|c|c|c|}
\hline \multicolumn{2}{|c|}{$\mathrm{MC}_{1}$} & \multicolumn{2}{|c|}{$\mathrm{MC}_{2}$} & \multicolumn{2}{|c|}{$\mathrm{MC}_{3}$} & \multicolumn{2}{|c|}{$\mathrm{MC}_{4}$} & \multicolumn{2}{|c|}{$\mathrm{MC}_{5}$} \\
\hline $\mathrm{EC}_{50}(\mathrm{~mol} / \mathrm{L})$ & $\operatorname{Max}(\%)$ & $\mathrm{EC}_{50}(\mathrm{~mol} / \mathrm{L})$ & $\operatorname{Max}(\%)$ & $\mathrm{EC}_{50}(\mathrm{~mol} / \mathrm{L})$ & $\operatorname{Max}(\%)$ & $\mathrm{EC}_{50}(\mathrm{~mol} / \mathrm{L})$ & $\operatorname{Max}(\%)$ & $\mathrm{EC}_{50}(\mathrm{~mol} / \mathrm{L})$ & $\operatorname{Max}(\%)$ \\
\hline $6.6 \times 10^{-8}$ & $109 \pm 3$ & $2.4 \times 10^{-4}$ & $38 \pm 3$ & $6.0 \times 10^{-8}$ & $104 \pm 18$ & $1.8 \times 10^{-7}$ & $116 \pm 1$ & $9.0 \times 10^{-7}$ & $102 \pm 7$ \\
\hline
\end{tabular}

Data report calculated $\mathrm{EC}_{50}$ values and maximal responses (Max) as determined using cells transfected with the indicated human MC receptors. AP214 was added for up to 30 minutes (see Materials and Methods), and accumulation of intracellular cAMP was determined by enzyme immunoassay. See Materials and Methods for details on cell types used, incubation periods, and temperatures. Maximal responses are given as mean \pm SD. Values are representative of three separate analyses.

utes with $\alpha$-MSH using the cAMP Biotrak enzyme immunoassay system (Amersham, Abingdon, UK).

\section{RNA Extraction, cDNA Synthesis, and Real-Time $P C R$}

Total RNA was extracted using the RNeasy mini kit and genomic DNA was removed by on-column digestion using the RNase-Free DNase set, following the manufacturer's instructions (QIAGEN Ltd, Crawley, UK). cDNA was synthesized using $1 \mu \mathrm{g}$ of pooled RNA from three or more replicates using SuperScript III Reverse Transcriptase (Invitrogen, Paisley, UK). Real-time PCR was performed in duplicate or triplicate, with $200 \mathrm{ng}$ of cDNA per well, $1 \mu \mathrm{L}$ of primers, and Power SYBR Green PCR master mix (Applied Biosystems, Warrington, UK), using the ABI Prism $7900 \mathrm{HT}$ sequence detection system (Applied Biosystems). The following QuantiTect primers (QIAGEN Ltd) were used: Gapdh (QT01658692), Anxa1 (QT00145915), I/1b (QT01048355), II6 (QT00098875), Tnf (QT00104006), TIr2 (QT00129752), TIr4 (QT00259042), Ptgs2 (QT00165347), and Nos2 (QT00100275). A dissociation step was always included to confirm the absence of unspecific products. TaqMan gene expression assays (Applied Biosystems) were used to quantify MC receptor genes (Mc1r: Mm00434851_s1, Mc3r: Mm00434876_s1, Mc5r: Mm00442970_m1, and Gapdh: Mm99999915_g1). PCR reaction was performed with $100 \mathrm{ng}$ of CDNA, $1 \mu \mathrm{L}$ of primers, and $10 \mu \mathrm{L}$ of $2 \mathrm{X}$ TaqMan gene expression master mix (Applied Biosystems). Fold change was calculated as $2^{-\Delta \Delta C}$ T using Gapdh as endogenous control.

\section{Statistics}

All the experiments were performed at least in triplicate and were repeated two to five times. The $t$-test, one-way analysis of variance followed by Dunnett's correction, two-way analysis of variance followed by Bonferroni correction, or the log-rank (Mantel-Cox) test was applied as appropriate, with $P \leq 0.05$ considered statistically significant.

\section{Results}

\section{AP214 Is a Pan Agonist at Human MC Receptors}

The data obtained in the in vitro $\mathrm{MC}$ receptor functional assays revealed that $\mathrm{AP} 214$ is a full pan $\mathrm{MC}$ receptor agonist (ie, a full agonist against $\mathrm{MC}_{1}, \mathrm{MC}_{3}, \mathrm{MC}_{4}$, and
$\mathrm{MC}_{5}$ ) and, similar to many other MCs, lacks agonist activity against $\mathrm{MC}_{2}$ (Table 1 ).

\section{AP214 and Zymosan-Induced Peritonitis}

This study began by testing the effect of AP214 in a model of sterile peritonitis, ${ }^{25}$ testing two different doses (400 and $800 \mu \mathrm{g} / \mathrm{kg}$ ) in $\mathrm{WT} \mathrm{MC}_{1}{ }^{-1-}$ and $\mathrm{MC}_{3}{ }^{-1-}$ mice. Injection of zymosan elicited a marked accumulation of neutrophils at 4 hours, ranging from 8 to $12 \times 10^{6}$ cells per mouse, which did not differ significantly across genotype. In WT mice, administration of AP214 produced a dose-dependent inhibitory effect (a 30\% to $45 \%$ reduction) (Figure 1). Of interest, AP214 retained its full antiinflammatory capacity in mice bearing an inactive $\mathrm{MC}_{1}$ $\left(\mathrm{MC}_{1}{ }^{-1-}\right)$, producing essentially a similar degree of inhibition on cell trafficking as in WT animals, whereas its effects were lost in the absence of $\mathrm{MC}_{3}$ receptor (Figure 1). Table 2 reports the original values of neutrophil trafficking as measured in these experiments. On these bases, we then tested the effects AP214 on macrophages collected from these mice, using cytokine production as readouts.

\section{Characterization of the MC System in Bio-Gel-Elicited Macrophages}

To study the anti-inflammatory properties of AP214 at the cellular level, including assessing the potential role of the two MC receptors, Bio-Gel-elicited peritoneal macrophages were used. Thus, we initially validated the cells with respect to the MC system. RT-PCR demonstrated that these

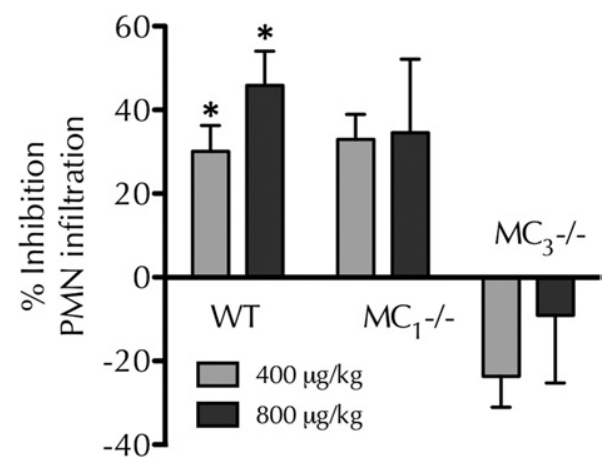

Figure 1. The modulation of zymosan-induced peritonitis by AP214. Mice were pretreated i.p. with vehicle or AP214 ( 400 or $800 \mu \mathrm{g} / \mathrm{kg}$ ) 30 minutes before i.p. injection of $1 \mathrm{mg}$ of zymosan. Neutrophil infiltration was measured 4 hours later by cell counting and Ly6G staining. Data are the mean \pm SEM of six mice per group. ${ }^{*} P<0.05, t$-test versus vehicle-treated group. PMN, polymorphonuclear cell. 
Table 2. AP214 Inhibits Neutrophil Recruitment in the Zymosan Peritonitis Model

\begin{tabular}{lrrrr}
\hline & WT & \multicolumn{1}{c}{$\mathrm{MC}_{1}{ }^{-1-}$} & \multicolumn{1}{c}{$\mathrm{WT}$} & $\mathrm{MC}_{3}{ }^{-/-}$ \\
\hline Vehicle & $23.29 \pm 2.72$ & $24.5 \pm 5.16$ & $13.29 \pm 1.09$ & $10.10 \pm 1.40$ \\
AP214, 400 $\mu \mathrm{g} / \mathrm{kg}$ & $15.09 \pm 2.91$ & $16.25 \pm 1.21$ & $9.99 \pm 1.51$ & $1.10 \pm 1.61$ \\
AP214, 800 $\mu \mathrm{g} / \mathrm{kg}$ & $13.57 \pm 3.53$ & $15.63 \pm 3.37$ & $6.54 \pm 4.47$ & $10.80 \pm 1.38$ \\
\hline
\end{tabular}

Reported are the numbers of neutrophils infiltrating the peritoneal cavity 4 hours after injection of zymosan (1 mg). AP214 was given i.p. 30 minutes before zymosan. Data, expressed as $10^{6}$ cells per cavity, are the mean \pm SEM of six mice per group. See Figure 1 for analysis as percentage of inhibition.

primary cells express the products of the mouse genes Mc1r, Mc3r, and Mc5r (Figure 2A). These receptors are functional because cell incubation with $\alpha$-MSH led to intracellular accumulation of CAMP (Figure 2B).

We then assessed the properties of two validated MC peptides on cytokine production. Figure $2 \mathrm{C}$ shows these data, with $\alpha$-MSH and D-Trp ${ }^{8}-\gamma$-MSH abolishing zymosan-induced IL-1 $\beta$ release and marginally, yet significantly, reducing TNF- $\alpha$ release after stimulation with zymosan. In the control samples, we determined cell expression of mRNA for three $\mathrm{MC}$ receptors, Mc1r, Mc3r, and $M c 5 r$, noting that on treatment with zymosan, there was a modest or null modulation in $\mathrm{WT}$ and $\mathrm{MC}_{1}{ }^{-1-}$
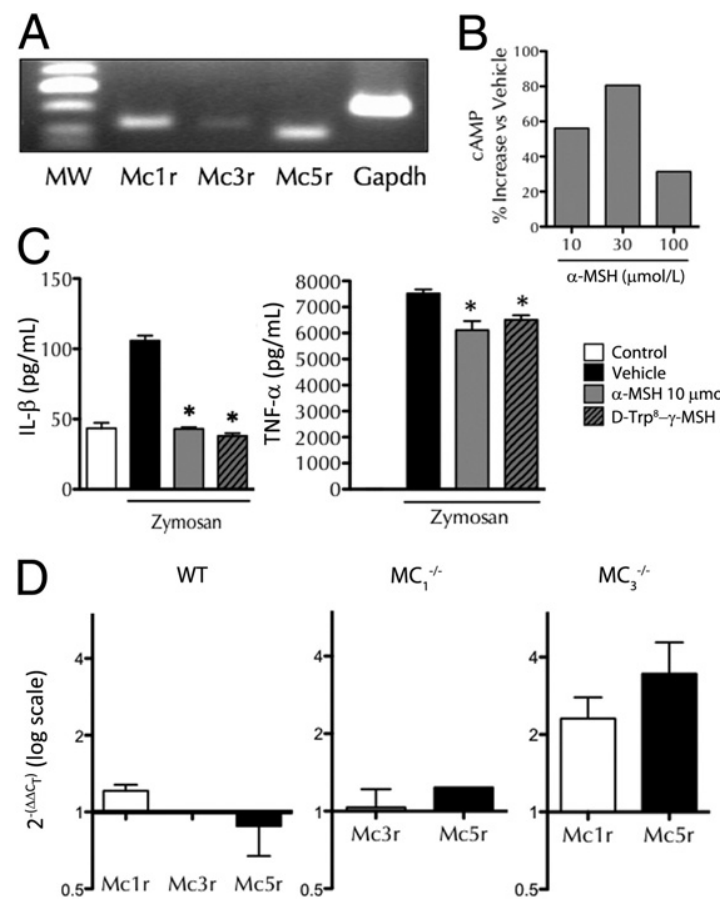

Figure 2. The MC system in Bio-Gel-elicited peritoneal macrophages. A: Measurement of MC receptor gene expression by RT-PCR. RNA was extracted using RNeasy mini columns, and genomic DNA was removed by on-column digestion. RT-PCR was performed using QuantiTect primers and products visualized on $3 \%$ agarose gels. MW, molecular weight. B: cAMP production was measured by enzyme immunoassay after stimulation with the reported concentrations of $\alpha$-MSH for 30 minutes. Control levels of cAMP in vehicletreated cells ranged from 0.97 to $1.2 \mathrm{nmol} / \mathrm{mL}$. C: Cytokine production. Macrophages were pretreated with $\alpha$-MSH and D-Trp ${ }^{8}-\gamma$-MSH for 30 minutes and then were stimulated with $25 \mu \mathrm{g} / \mathrm{mL}$ of zymosan for 6 hours. Cytokines released in the supernatants were quantified by ELISA. ${ }^{*} P<0.05$, one-way analysis of variance followed by Dunnett's correction. D: Gene expression modulation of $M c 1 r, M c 3 r$, and $M c 5 r$ on zymosan-treated cells. Real-time PCR was performed using TaqMan gene expression assays on macrophages (WT, $\mathrm{MC}_{1}^{-1-}$, and $\mathrm{MC}_{3}^{-1-}$ cells) stimulated with $25 \mu \mathrm{g} / \mathrm{mL}$ of zymosan for 6 hours. Data are relative to nonstimulated cells (PBS treated) and normalized to Gapdh gene. Data are mean \pm SEM. macrophages (Figure 2D). In contrast, when $\mathrm{MC}_{3}^{-1-}$ cells were used, the "inflammatory status" produced by zymosan led to marked gene activation for Mc1r and Mc5r (Figure 2D).

\section{Anticytokine Effect of AP214 in Primary Macrophages}

Once the model was characterized, Bio-Gel-elicited macrophages obtained from $\mathrm{WT}, \mathrm{MC}_{1}{ }^{-1-}$, and $\mathrm{MC}_{3}{ }^{-1-}$ mice were used to study whether MC stimulation by AP214 could affect zymosan-induced cytokine release. The release of IL-6, TNF- $\alpha$, and IL-1 $\beta$ was significantly reduced by AP214 in WT cells and in $\mathrm{MC}_{1}{ }^{-1-}$ macrophages (Figure 3). The effect on IL-1 $\beta$ reduction was particularly prominent in both cases. However, this potent inhibition of IL-1 $\beta$ release was lost in $\mathrm{MC}_{3}{ }^{-1-}$ cells. In the latter cells, AP214 was still active in reducing IL-6 and TNF- $\alpha$, suggesting additional mechanisms and/or receptor targets.
IL-1 $\beta$

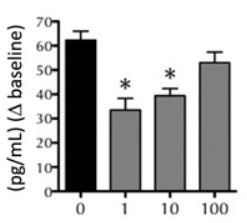

$\mathrm{MC}_{1}=\underbrace{1-}_{1}$

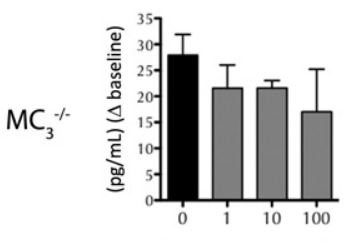

IL-6
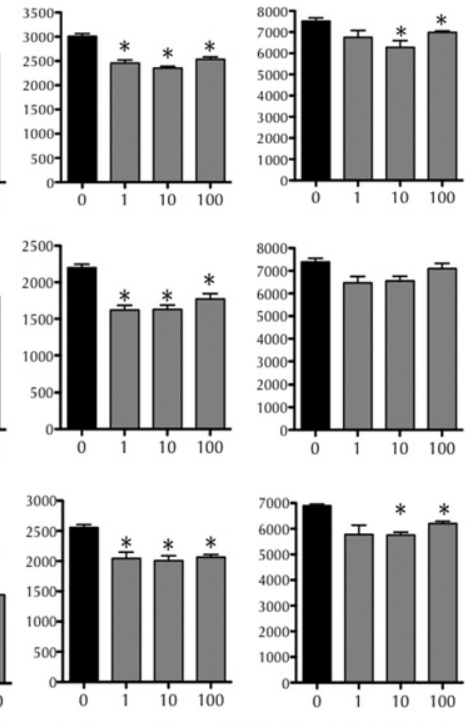

AP214 (nmol/L)

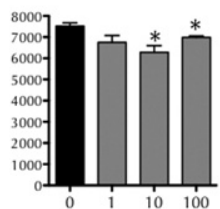

TNF- $\alpha$

\section{WT}

Figure 3. The modulation of cytokine release from zymosan-stimulated macrophages by AP214. Bio-Gel-elicited peritoneal macrophages were collected from WT, $\mathrm{MC}_{1}{ }^{-/-}$, and $\mathrm{MC}_{3}{ }^{-/-}$mice by peritoneal lavage and were cultured for 1 hour to allow adherence. Cells ( $>90 \%$ macrophages) were then washed and pretreated with AP214 for 30 minutes before the addition of zymosan $(25 \mu \mathrm{g} / \mathrm{mL})$; supernatants were harvested 6 hours later and were tested for IL- $1 \beta$, IL- 6 , and TNF- $\alpha$ contents by ELISA. Data are mean \pm SEM of three experiments in triplicate. ${ }^{*} P<0.05$, one-way analysis of variance followed by Dunnett's correction. 

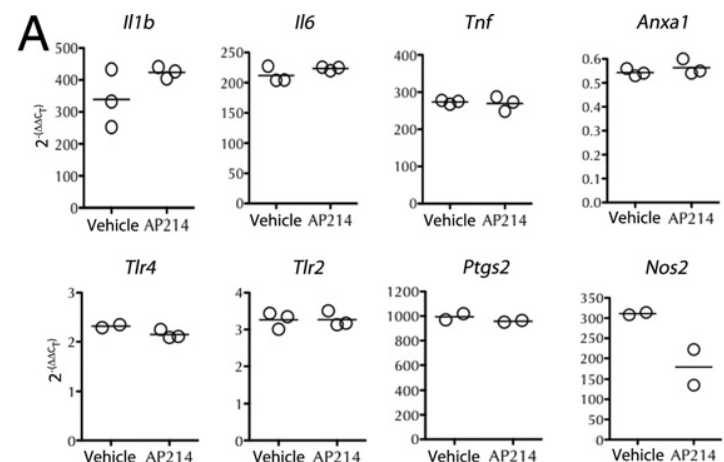

TIr2
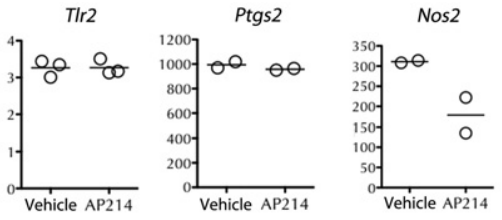

B

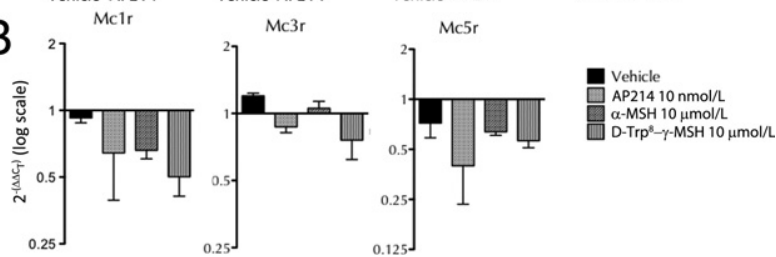

Figure 4. The modulation of gene expression by AP214. A: Pooled RNA from three replicates was extracted from Bio-Gel-elicited macrophages pretreated with AP214 stimulated with zymosan as in Figure 3. SYBR Green and QuantiTect primers were used. Data are relative to non-zymosan-stimulated cells and normalized to Gapdh gene. B: MC gene expression was measured in the same conditions using TaqMan gene expression assays. Data are the mean \pm SEM.

\section{AP214 and Gene Expression Induced by Zymosan}

To determine whether the anticytokine effect on WT macrophages was related to the regulation of gene expression, we measured several genes using quantitative realtime PCR. As illustrated in Figure 4A, AP214 (10 nmol/L) didn't reduce mRNA levels of $\| 1 \mathrm{~b}$, $/ 16$, and Tnf genes, which were markedly up-regulated by zymosan. The same result was obtained for other genes that were measured, including those for the anti-inflammatory protein annexin 1A (Anxa1), toll-like receptors 2 and 4 (TIr2 and T/r4), and prostaglandin synthase 2 (Ptgs2). However, AP214 reduced gene expression of the inducible nitric oxide synthase (Nos2) by 50\% compared with vehicletreated cells (Figure 4A).

Having noted the effect of zymosan on MC receptor gene expression (Figure 2D), we then tested the effect of MC peptides. The results indicate the existence of a general trend to reduce $\mathrm{MC}$ receptor gene expression in cells treated with $\mathrm{MC}$ compounds (Figure 4B); in these experiments, Mc1r and Mc5r seemed to be modulated by cell incubation with the MC peptides.

\section{Prophagocytic Activity of AP214 on Zymosan Clearance by Macrophages}

Once the anti-inflammatory and anticytokine effects of AP214 were established, we then questioned whether this $\mathrm{MC}$ peptide, chosen as a prototype for this family of anti-inflammatory compounds, could be endowed with proresolving properties. We began by testing the phagocytic ability of macrophages.

Time course analysis of zymosan particle ingestion by macrophages revealed a significant potentiating effect for AP214 (Figure 5A), a 10-nmol/L concentration being selected from the results of $\mathrm{IL}-1 \beta$ release. In this set of experiments, cell incubation with AP214 accelerated the rate of phagocytosis, with augmented responses in the percentage of phagocytosing macrophages (Figure 5A, left) and the phagocytic index (Figure 5A, right), the latter assessed by the number of particles ingested by each

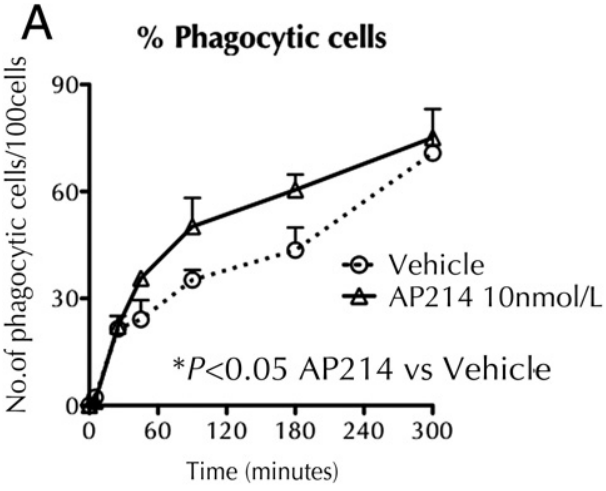

B

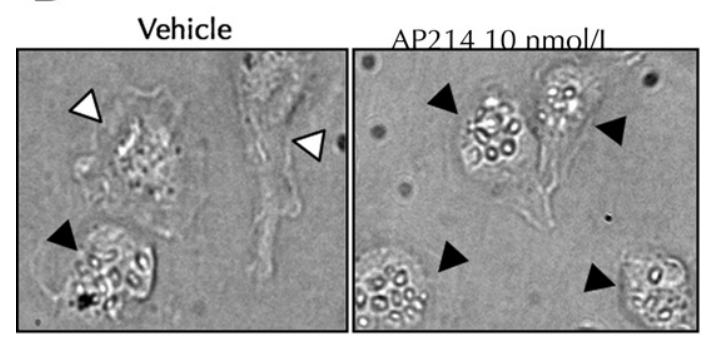

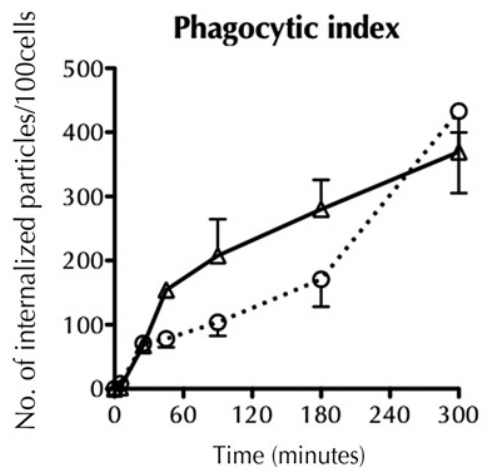

C

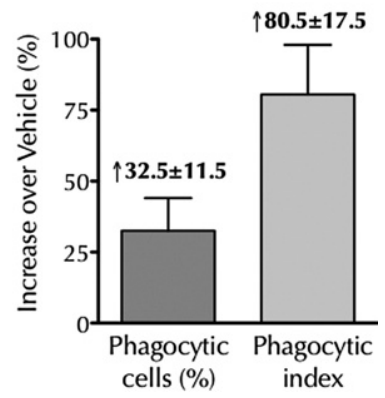

Figure 5. Prophagocytic properties of AP214. Bio-Gel-elicited macrophages were pretreated with vehicle or AP214 for 30 minutes. Zymosan was then added at a 1:5 ratio (macrophage/zymosan particles), and, at selected time points, cells were vigorously washed to remove noningested particles and images acquired using light microscopy. The percentage of phagocytic cells and the number of particles ingested were analyzed. An average of 250 cells were analyzed per group. A: Time course analysis of phagocytosis. ${ }^{*} P<0.05$, two-way analysis of variance followed by Bonferroni correction. B: Representative images of treated and nontreated cells. Black arrowheads point to phagocytic cells and white arrowheads to nonphagocytic cells C: Pooled data from four independent experiments conducted 1.5 hours after zymosan stimulation. Data are the mean \pm SEM. 


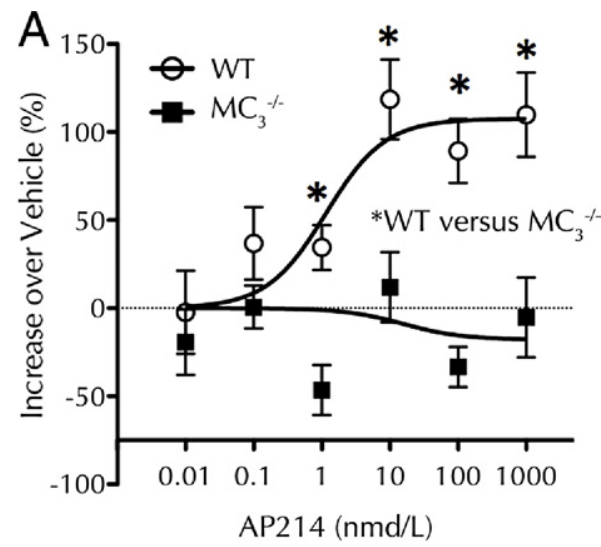

B

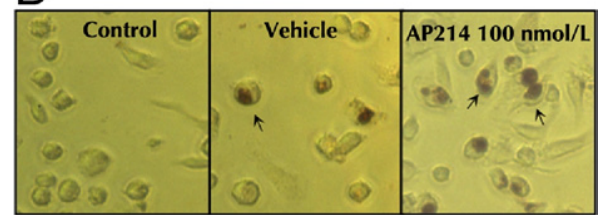

Figure 6. In vitro pro-efferocytic properties of AP214. Apoptotic neutrophils were added to Bio-Gel-elicited macrophages (obtained from WT or $\mathrm{MC}_{3}{ }^{-1}$ mice) previously pretreated with vehicle or AP214 at a ratio of 1:2 (macrophage/neutrophils) and were incubated for 1 hour. Cells were then washed to remove noningested neutrophils, and the MPO assay was performed to selectively stain intracellular neutrophils. Images were acquired by light microscopy assessing more than 400 cells per treatment. A: Concentrationresponse effect of AP214 on efferocytosis. Data are the mean \pm SEM. ${ }^{*} P<$ 0.001 , two-way analysis of variance followed by Bonferroni correction. The mean \pm SEM proportion of phagocytic macrophages at basal levels was $9.7 \% \pm 1.4 \%$. B: Representative images of WT cells after the MPO assay was performed. Arrows identify macrophages that have intenalised an apoptotic neutrophil. Note the lack of staining in the control group, denoting the selectivity of the assay.

cell. Figure 5B shows representative images of vehicleand AP214-treated macrophages.

Cumulative data for this assay of phagocytosis are shown in Figure 5C, as determined at the selected time point of 90 minutes after zymosan addition, with marked effects for AP214.

\section{Proresolving Actions of AP214: Effect on Efferocytosis in Vivo and in Vitro}

Next, we explored whether AP214 could increase the clearance of apoptotic neutrophils because this is a cru- cial process in the resolution of inflammation. ${ }^{1}$ In vitro experiments were run to test a full concentration range of AP214: incubation of the macrophages with this compound profoundly incremented the phagocytosis of human apoptotic neutrophils after 1 hour of incubation, tested as MPO-positive macrophages, with approximately twofold augmentation over vehicle at $\geq 10-\mathrm{nmol} / \mathrm{L}$ concentrations (Figure 6A). In cumulative experiments performed with distinct cell preparations, AP214 provoked a marked increase (mean \pm SEM of 3 independent experiment: $70.3 \% \pm 10.2 \%$ ) in the phagocytosis of apoptotic neutrophils. The pro-efferocytosis effect of AP214 was absent in macrophages prepared from $\mathrm{MC}_{3}{ }^{-1-}$ mice (Figure 6A). Figure $6 \mathrm{~B}$ shows representative images for this set of experiments.

Once established that the prophagocytic actions are mediated through $\mathrm{MC}_{3}$ receptors, we then studied whether the activating property of AP214 was also observed in vivo. To this end, human apoptotic neutrophils were fluorescently labeled and injected i.p. into WT mice pretreated with AP214. Analysis of neutrophil ingestion by the macrophages revealed a dose-dependent increase in uptake, as determined at 1 hour, with significant effect at the dose of $800 \mu \mathrm{g} / \mathrm{kg}$ (Figure 7).

\section{Effect of AP214 in the K/BXN Serum Transfer Arthritis Model}

Finally, we determined whether these anti-inflammatory and proresolving properties of AP214 could afford pharmacologic effects in a clinically relevant model. We chose the $\mathrm{K} / \mathrm{B} \times \mathrm{N}$ serum transfer arthritis model because it is highly reliant on $\mathrm{IL}-1 \beta$, with the involvement of macrophages, together with neutrophils and mast cells, as central players. ${ }^{26}$

WT mice were treated i.p. twice daily with 400 and $800 \mu \mathrm{g} / \mathrm{kg}$ per dose starting from day 0 , that is, the day of i.p. injection of the arthrogenic serum. All the variables measured were reduced by AP214, particularly when given at the dose of $400 \mu \mathrm{g} / \mathrm{kg}$. For example, disease incidence was reduced to $50 \%$ at the peak of the disease (days 4 to 8 after serum administration) (Figure 8). Significant reductions in disease score and paw edema could also be measured for the AP214 dose of $400 \mu \mathrm{g} / \mathrm{kg}$. In contrast, no antiarthritic effect
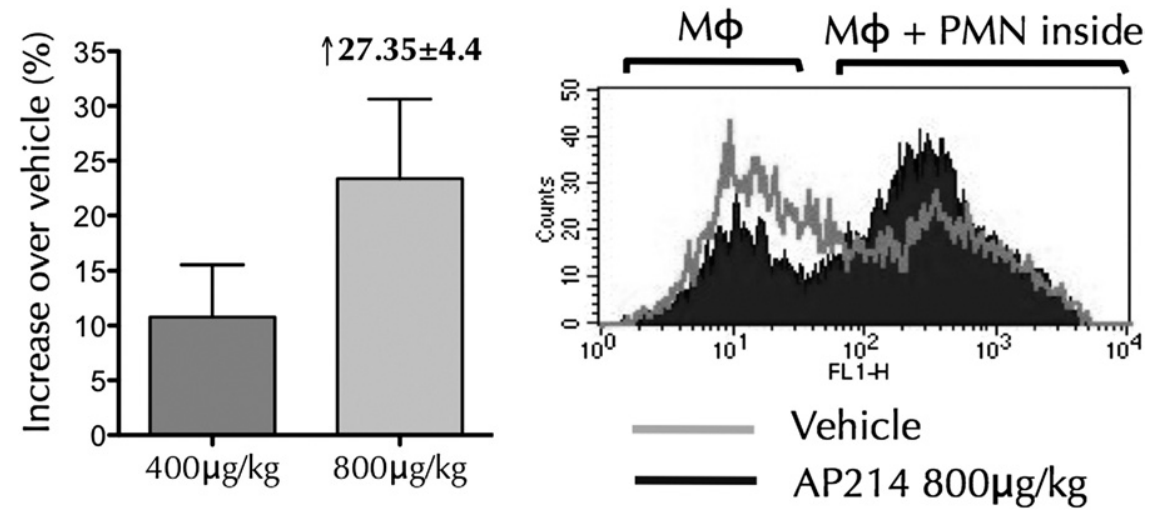

Figure 7. In vivo pro-efferocytic actions of AP214. Mice were treated i.p. with vehicle or AP214 (at the reported doses), and 30 minutes later apoptotic neutrophils (stained with CFSE) were injected $\left(3 \times 10^{6}\right.$ cells i.p.). Animals were sacrificed after another 30 minutes, and peritoneal lavages were analyzed by flow cytometry. Data are the mean \pm SEM of four mice per group. $\mathrm{M} \Phi$, macrophages; PMN, polymorphonuclear cell; FL1-H, CFSE fluorescence intensity. 
Disease incidence

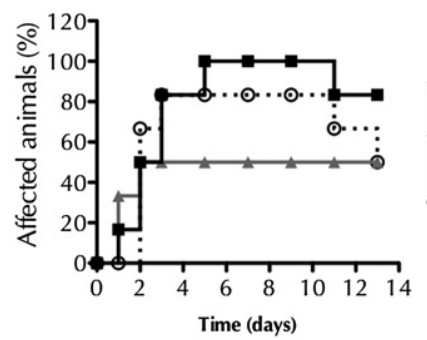

Disease Score

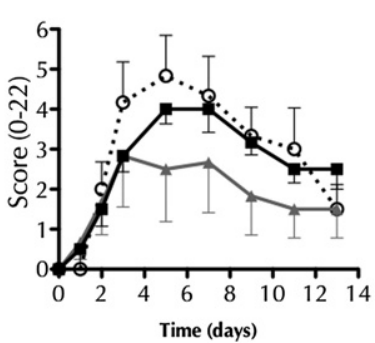

Paw volume

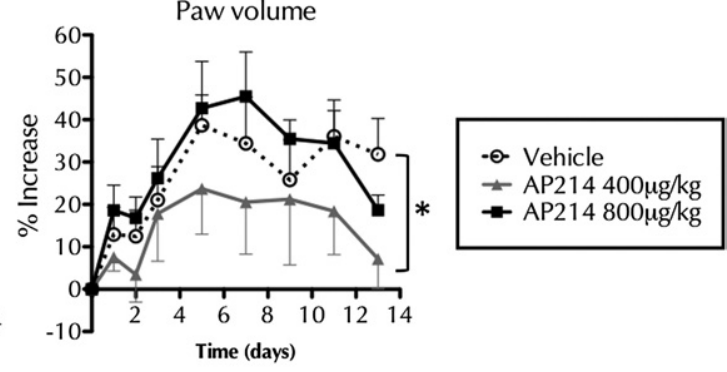

Figure 8. Anti-inflammatory actions of AP2 14 on K/BxN serum transfer arthritis. Mice were injected i.p. with $100 \mu \mathrm{L}$ of K/BxN serum at day 0 and were treated twice daily i.p. with vehicle (PBS) or AP214 for 10 days. Disease was monitored for 2 weeks. Data are the mean \pm SEM of six mice per group. ${ }^{*} P<0.05$. One-way analysis of variance followed by Dunnett's multiple comparison test on area under the curve values and log-rank (Mantel-Cox) tests were performed when appropriate.

was evident when AP214 was administered twice daily at the high dose of $800 \mu \mathrm{g} / \mathrm{kg}$.

\section{Discussion}

This study presents novel data indicating that the pan MC receptor agonist AP214 is endowed with anti-inflammatory properties mainly conveyed through the $\mathrm{MC}_{3}$ receptor. Furthermore, we provide evidence that agonism at this receptor can promote proresolving responses, including particle containment and efferocytosis. We propose that these cellular events are responsible, at least partly, for the tissue-protective properties of AP214.

There is a strong need for the discovery of new drugs with higher potency, fewer adverse effects, and lower cost than those currently available to be enrolled in longterm treatment regimens. A novel approach to drug discovery, based on the study of the body's own natural resolution mechanisms, is currently emerging and finding acceptance in the scientific community ${ }^{27,28}$ : MC analogues would fit into this novel category. So far, most efforts have been devoted to the development of $\mathrm{MC}_{4}$ agonists with potential use in obesity and sexual dysfunction, and there have been a few attempts to exploit the potential use of MC compounds as anti-inflammatory drugs. One reason behind this lack of development could be identification of the MC receptor to be targeted to elicit the desired anti-inflammatory effects, with studies pointing to each of $\mathrm{MC}_{1},{ }^{29} \mathrm{MC}_{3},{ }^{10}$ and, more recently, $\mathrm{MC}_{5}{ }^{30}$ Some clinical trials using $\alpha$-MSH or corticotropin are currently under way to test the efficacy on acute renal failure, multiple sclerosis, and idiopathic membranous nephropathy, with compound AP214 being under clinical evaluation for preventing kidney injury after cardiac surgery (http://www. clinicaltrials.gov).

On peritoneal injection, zymosan induces an inflammatory reaction characterized by initial activation of resident macrophages and mast cells ${ }^{25}$ followed by intense infiltration of blood-borne neutrophils, with involvement of the complement system and several cytokines and mediators. AP214, given to mice as a pretreatment, elicited significant attenuation of these responses. This effect was totally dependent on $\mathrm{MC}_{3}$, as determined using null mice, confirming previous data produced in this animal species with $\alpha-\mathrm{MSH}$ and D-Trp ${ }^{8}-\gamma-\mathrm{MSH}^{7,9}$ It, therefore, seems that $\mathrm{MC}_{3}$, probably expressed on resident mac- rophages and mast cells, ${ }^{31}$ may be activated by AP214 to inhibit cell recruitment in response to zymosan peritonitis. We recently investigated the behavior of $\mathrm{MC}_{3}$ null mice in models of vascular inflammation reporting the existence of an inhibitory tone for this receptor so that in its absence, augmented degrees of leukocyte adhesion and emigration could be measured. ${ }^{9}$ It seems that in the mouse, $\mathrm{MC}_{3}$ might sustain physiologic and pharmacologic effects, including those elicited by AP214. The mechanistic association between AP214 and $\mathrm{MC}_{3}$ and is not only based on the in vivo data but also emerges from the results obtained with cytokine release from macrophages. Cell incubation with AP214 reduced cytokine release, including IL-6, TNF- $\alpha$, and, particularly, IL-1 $\beta$, by primary peritoneal macrophages. Inhibition of $\mathrm{IL}-1 \beta$ release was fully reliant on $\mathrm{MC}_{3}$, whereas this was not the case for the effect on the other two cytokines. It might be possible that $\mathrm{MC}_{5}$ receptor is mediating this effect on IL-6 and TNF- $\alpha$ because we found up-regulation of this receptor in $\mathrm{MC}_{3}$-deficient macrophages. To further study whether the anticytokine effect was related to gene expression modulation, we studied the effect of $10 \mathrm{nmol} / \mathrm{L}$ AP214 using real-time PCR. No differences were observed in cytokine mRNA levels and with respect to a series of other genes (eg, T/r2) compared with control cells, the exception being Nos2 gene expression, which was markedly reduced by AP214 treatment. This result might be linked to the anti-inflammatory property of AP214 in zymosan peritonitis because NOS-2 protein induction is conducive to neutrophil migration in this model. ${ }^{32}$

Lack of effect on gene expression, and involvement of posttranscriptional processes, is not unique to AP214. Indeed, $\alpha$-MSH inhibits CXCR type 1 and 2 protein levels by increasing neutrophil elastase levels and activity with consequent membrane shedding. ${ }^{33}$ In addition, inhibition of responses evoked by lipopolysaccharide on macrophages by $\alpha-\mathrm{MSH}$ is due to a reduction of CD14 on the macrophage membrane, with shedding into the supernatants. ${ }^{15}$ It is plausible that AP214 inhibition of IL-1 $\beta$ processing, which yielded much higher effect than on TNF- $\alpha$ or IL-6, might indicate exquisite $\mathrm{MC}_{3}$-mediated modulation of the inflammasome. Clearly, this would be the scope of future studies using AP214 or more selective $\mathrm{MC}_{3}$ agonists, although an interesting hypothesis can be put forward: the efficacy of adrenocorticotrophin in hu- 
man gouty arthritis, ${ }^{34}$ and many other MCs in rodents, ${ }^{35}$ could be due to the fact that urate crystals activate the inflammasome, ${ }^{36}$ and, indeed, the abnormality is highly reliant on $\mathrm{IL}-1 \beta,{ }^{37}$ so inhibition of the release of this cytokine would be a major determinant for MC compound efficacy.

The studies of gene expression revealed other interesting observations that may become groundbreaking in the MC area. On zymosan-stimulated macrophages, treatment with different MC agonists $\left(\alpha-\mathrm{MSH}, \mathrm{D}-\mathrm{Trp}^{8}{ }_{-}\right.$ $\gamma$-MSH, and AP214) provoked modulation of MC gene expression. All three receptors studied, Mc1r, Mc3r, and $M c 5 r$, displayed reduced mRNA expression in cells treated with the peptides compared with vehicletreated cells; we postulate that such a cellular response may explain the often observed lack of efficacy at higher concentrations of MC peptides, hence the bell-shaped responses typically observed with these compounds. Nongenomic effects can also be elicited by $\gamma-\mathrm{MSH}$, and, for example, in neurons, $\mathrm{MC}_{3}$ can be rapidly internalized on application of its ligand. ${ }^{38}$ Thus, MC ligands can potentially regulate MC receptor expression in a variety of ways.

Equally of interest is the modulation of $M C$ receptor gene expression comparing stimulated and nonstimulated macrophages. $\mathrm{MC}_{3}{ }^{-1-}$ cells treated with zymosan exhibited an increase in the other receptor mRNAs, $M c 1 r$ and $M c 5 r$, suggesting the existence of a compensatory mechanism in the absence of $\mathrm{MC}_{3}$. Furthermore, $\mathrm{MC}_{3}$ may sustain a crucial role in inflammation because this compensation is not observed in WT or $\mathrm{MC}_{1}{ }^{-1-}$ cells. Note that similar observations also have recently been made in the arthritic joint, with Mc1r mRNA elevated in the inflamed joints of $\mathrm{MC}_{3}{ }^{-1-}$ mice. ${ }^{10}$ These findings allow us to propose a novel model whereby $\mathrm{MC}_{1}$ could be indicated as the physiologic receptor, with an almost ubiquitous distribution in a variety of cell types, whereas $\mathrm{MC}_{3}$ (and, in a tissue-specific manner, $\mathrm{MC}_{5}$ ) could be a "stress receptor" up-regulated in conditions of tissue injury or inflammation. The proposed model would require corroboration in further studies, but, if confirmed, it could inform the development of selective MC receptor agonists for a specific pathologic disorder.

Once we had studied the anti-inflammatory properties of AP214, we sought to use this compound to explore novel activities related to the resolution of inflammation, an emerging field that has witnessed rapid progress in the past few years. ${ }^{1,27}$ Resolution is an active process consisting of the activation of endogenous pathways during the inflammatory response that counteracts the deleterious consequences to the host due to chronic inflammation; in other words, resolution is not just blockade of neutrophil migration or reduction of cytokine generation but the active engagement of homeostatic processes, including phagocytosis and efferocytosis, to ensure regain of the pre-inflammatory status of a tissue. Because AP214 could modulate zymosan-induced macrophage activation, we then studied whether it could also modulate the phagocytic ability of these cells.

First, we studied the action of AP214 on zymosan phagocytosis, as several proresolving mediators have previously been demonstrated to play an important role in this process. Annexin A1 null macrophages exhibit a defect in zymosan and bacteria uptake, ${ }^{39}$ and the lipid mediators maresins and resolvins can increase phagocytosis of zymosan. ${ }^{28,40}$ The present results show that the MC peptide AP214 (10 nmol/L) increases clearance of zymosan particles by macrophages in vitro. AP214-induced stimulation of zymosan ingestion by the macrophages was reflected as the number of cells engulfed with the particles and the apparent amount of particles ingested, as indicated by the phagocytic index. An important annotation is due here in relation to the receptor mechanisms activated by zymosan to promote cytokine release (an effect reliant on TLR2 activation) and phagocytosis [mediated by Dectin-1 and complement receptor 3 (CD11b/CD18)], two processes functionally separated yet occurring simultaneously. ${ }^{41}$ In these experiments, AP214 could modulate zymosan-activated processes irrespective of the receptor/pathway engaged by the inflammogen.

Neutrophils die by apoptosis at the site of inflammation, and removal of these cells before they turn necrotic is crucial because they would otherwise release the contents of their granules with the potential to cause further damage to the tissue. ${ }^{42,43}$ Furthermore, recognition of apoptotic neutrophils exerts additional anti-inflammatory effects because it leads back to inhibit the release of pro-inflammatory mediators and activate the production of anti-inflammatory IL-10 and TGF- $\beta .^{44-46}$ Many proinflammatory mediators, such as annexin A1, glucocorticoid, and lipoxin $A_{4}$, have been shown to produce proefferocytic effects, ${ }^{47-49}$ but no data are available with respect to $\mathrm{MC}$ receptor agonists. Using plate-based and validated in vivo protocols, ${ }^{23,24}$ we observed that AP214 evoked a marked increase in the phagocytosis of human apoptotic neutrophils by cultured macrophages in vitro (with an increment of $\sim 70 \%$ ) and resident peritoneal macrophages in vivo (30\%). These results name, for the first time, MC peptides with the group of proresolving mediators. We speculate that this effect can be relevant to the tissue-protective properties of AP214 ${ }^{19}$ and other $\mathrm{MC}$ agonists. ${ }^{50}$ In all our settings, these proresolving effects require $\mathrm{MC}_{3}$ expression. Future investigation will address the molecular pathways (after $\mathrm{MC}_{3}$ activation by AP214) responsible for the observed pro-efferocytic response. It is worth noting, though, that the pro-efferocytic response is unlikely linked to CAMP accumulation because CAMP-elevating strategies induce a lower degree of macrophage phagocytosis. ${ }^{51}$ Perhaps the peculiarity of $\mathrm{MC}_{3}$, shown to induce postreceptor pathways distinct from sole cAMP accumulation, ${ }^{18}$ could yield novel molecular clues for the observed responses. On the other hand, emerging evidence indicates that the level of cAMP accumulation might lead to distinct outcomes, with a low degree of activation promoting efferocytosis. ${ }^{52}$ This recent study shows how a low degree of cAMP accumulation, after activation of the specific G-protein-coupled receptor termed G2A, by prostaglandin $E_{2}$ augments macrophage efferocytosis of apoptotic neutrophils, a result perfectly aligned with that observed for AP214. Indeed, in experiments of cAMP accumulation in peritoneal 
macrophages, AP214 (100 nmol/L) increased values 50\% to $70 \%$ above control values, a modest response compared with that elicited by forskolin ( $3 \mu \mathrm{mol} / \mathrm{L})$, which yielded a $500 \%$ increment in cAMP formation. The degree of the response produced by macrophage incubation with AP214 is in line with that measured for $\alpha$-MSH (Figure 2B).

Note that changes in cAMP levels may also govern the differentiation of macrophages during the resolution phase of an acute inflammatory response, including the zymosan peritonitis model used herein. ${ }^{53}$ This event is unlikely to occur within the time frame of the experiments reported in the present study, but it may open interesting opportunities for AP214 and other MC receptor agonists when tested in more prolonged experimental, and clinical, settings. Future studies will address this potentially important new aspect of MC biology.

In the final part of the study, we addressed the question of whether AP214 could be therapeutic in more aggressive disease conditions, and we chose a model of inflammatory arthritis recently applied to study $\mathrm{MC}_{3}$ control in experimental chronic inflammation. ${ }^{10} \mathrm{~K} / \mathrm{BxN}$ serum arthritis is mainly driven by the innate immune system, with major roles being played by migrated neutrophils, resident mast cells, and macrophages, with $\mathrm{IL}-1 \beta$ having a consistent pathogenic role. ${ }^{26}$ Furthermore, clearance of apoptotic neutrophils from the synovial fluid has been suggested to be crucial to joint inflammation because dying neutrophils may help sustain the inflammatory response. ${ }^{2,54}$ AP214 produced promising results with respect to disease incidence, paw volume, and disease score, which were significantly reduced at the low dose of $400 \mu \mathrm{g} / \mathrm{kg}$. In contrast to the results produced in the peritonitis model, AP214 was inactive at $800 \mu \mathrm{g} / \mathrm{kg}$, a finding that may be related to the down-regulation of MC receptors discussed previously, because the compound was given twice daily over a 10-day regimen. In any case, this promising study justifies the assessment of AP214 in other experimental models of joint disease, especially those reliant in IL-1 $\beta$ (see previously herein), spanning from models of rheumatoid arthritis to models of gouty arthritis and osteoarthritis.

In summary, AP214 is endowed with anti-inflammatory properties, including inhibition of neutrophil migration and cytokine release. Novel activities were also revealed for AP214 and described for MC agonists as the increase in phagocytosis of zymosan particles and the pro-efferocytic effect, suggesting that activation of MC receptors can genuinely evoke proresolving circuits. These new data on phagocytosis and clearance of apoptotic neutrophils might open new potential applications of the compound in diseases where these processes are impaired, such as chronic obstructive pulmonary disease $e^{55,56}$ and cystic fibrosis. ${ }^{57}$ The present data also indicate a key role for $\mathrm{MC}_{3}$ as the main target activated by AP214 to bring about most of the effects presented herein. Together with a variety of studies conducted with other MCs, these new results emphasize the anti-inflammatory nature of $\mathrm{MC}_{3}$ and how it could be amenable to the design of novel anti-inflammatory and proresolving therapeutics.

\section{References}

1. Serhan CN, Savill J: Resolution of inflammation: the beginning programs the end. Nat Immunol 2005, 6:1191-1197

2. Nathan C, Ding A: Nonresolving inflammation. Cell 2010, 140:871882

3. Getting SJ, Flower RJ, Perretti M: Inhibition of neutrophil and monocyte recruitment by endogenous and exogenous lipocortin $1 . \mathrm{Br} J$ Pharmacol 1997, 120:1075-1082

4. Gonzalez-Rey E, Chorny A, Delgado M: Regulation of immune tolerance by anti-inflammatory neuropeptides. Nat Rev Immunol 2007 7:52-63

5. Levy BD, Lukacs NW, Berlin AA, Schmidt B, Guilford WJ, Serhan CN, Parkinson JF: Lipoxin A4 stable analogs reduce allergic airway responses via mechanisms distinct from CysLT1 receptor antagonism. FASEB J 2007, 21:3877-3884

6. Catania A: The melanocortin system in leukocyte biology. J Leukoc Biol 2007, 81:383-392

7. Getting SJ, Lam CW, Chen AS, Grieco P, Perretti M: Melanocortin 3 receptors control crystal-induced inflammation. FASEB J 2006, 20: 2234-2241

8. Getting SJ, Riffo-Vasquez Y, Pitchford S, Kaneva M, Grieco P, Page $\mathrm{CP}$, Perretti M, Spina D: A role for MC3R in modulating lung inflammation. Pulm Pharmacol Ther 2008, 21:866-873

9. Leoni G, Patel HB, Sampaio AL, Gavins FN, Murray JF, Grieco P Getting SJ, Perretti M: Inflamed phenotype of the mesenteric microcirculation of melanocortin type 3 receptor-null mice after ischemiareperfusion. FASEB J 2008, 22:4228-4238

10. Patel HB, Bombardieri M, Sampaio AL, D'Acquisto F, Gray M, Grieco P, Getting SJ, Pitzalis C, Perretti M: Anti-inflammatory and antiosteoclastogenesis properties of endogenous melanocortin receptor type 3 in experimental arthritis. FASEB J 2010, 24:4835-4843

11. Getting SJ, Schioth HB, Perretti M: Dissection of the anti-inflammatory effect of the core and C-terminal (KPV) $\alpha$-melanocyte-stimulating hormone peptides. J Pharmacol Exp Ther 2003, 306:631-637

12. Kannengiesser $K$, Maaser $C$, Heidemann J, Luegering A, Ross M, Brzoska T, Bohm M, Luger TA, Domschke W, Kucharzik T: Melanocortin-derived tripeptide KPV has anti-inflammatory potential in murine models of inflammatory bowel disease. Inflamm Bowel Dis 2008, 14:324-331

13. Wang CH, Lee TH, Lu CN, Chou WY, Hung KS, Concejero AM, Jawan B: Electroporative $\alpha$-MSH gene transfer attenuates thioacetamideinduced murine hepatic fibrosis by MMP and TIMP modulation. Gene Ther 2006, 13:1000-1009

14. Yoon SW, Lee $\mathrm{CH}$, Kim JY, Sung MH, Poo H: Lactobacillus casei secreting $\alpha-\mathrm{MSH}$ induces the therapeutic effect on DSS-induced acute colitis in Balb/c mice. J Microbiol Biotechnol 2008, 18:1975-1983

15. Sarkar A, Sreenivasan Y, Manna SK: $\alpha$-Melanocyte-stimulating hormone inhibits lipopolysaccharide-induced biological responses by downregulating CD14 from macrophages. FEBS Lett 2003, 553:286-294

16. Loser K, Brzoska T, Oji V, Auriemma M, Voskort M, Kupas V, Klenner L, Mensing C, Hauschild A, Beissert S, Luger TA: The neuropeptide $\alpha$-melanocyte-stimulating hormone is critically involved in the development of cytotoxic CD8 $+\mathrm{T}$ cells in mice and humans. PLoS One 2010, 5:e8958

17. Taylor A, Namba K: In vitro induction of CD25+CD4+ regulatory $\mathrm{T}$ cells by the neuropeptide $\alpha$-melanocyte stimulating hormone ( $\alpha$ MSH). Immunol Cell Biol 2001, 79:358-367

18. Gantz I, Fong TM: The melanocortin system. Am J Physiol Endocrinol Metab 2003, 284:E468-E474

19. Doi K, Hu X, Yuen PS, Leelahavanichkul A, Yasuda H, Kim SM, Schnermann J, Jonassen TE, Frokiaer J, Nielsen S, Star RA: AP214, an analogue of $\alpha$-melanocyte-stimulating hormone, ameliorates sepsis-induced acute kidney injury and mortality. Kidney Int 2008, 73: 1266-1274

20. Simmons MN, Subramanian V, Crouzet S, Haber GP, Colombo Jr Jr, Ukimura O, Nielsen S, Gill IS: $\alpha$-Melanocyte stimulating hormone analogue AP214 protects against ischemia induced acute kidney injury in a porcine surgical model. J Urol 2010, 183:1625-1629

21. Robbins LS, Nadeau JH, Johnson KR, Kelly MA, Roselli-Rehfuss L, Baack E, Mountjoy KG, Cone RD: Pigmentation phenotypes of variant 
extension locus alleles result from point mutations that alter $\mathrm{MSH}$ receptor function. Cell 1993, 72:827-834

22. Chen AS, Marsh DJ, Trumbauer ME, Frazier EG, Guan XM, Yu H, Rosenblum Cl, Vongs A, Feng Y, Cao L, Metzger JM, Strack AM, Camacho RE, Mellin TN, Nunes CN, Min W, Fisher J, Gopal-Truter S, Macintyre DE, Chen HY, Van der Ploeg LH: Inactivation of the mouse melanocortin-3 receptor results in increased fat mass and reduced lean body mass. Nat Genet 2000, 26:97-102

23. Hart SP, Dransfield I, Rossi AG: Phagocytosis of apoptotic cells. Methods 2008, 44:280-285

24. Taylor PR, Carugati A, Fadok VA, Cook HT, Andrews M, Carroll MC, Savill JS, Henson PM, Botto M, Walport MJ: A hierarchical role for classical pathway complement proteins in the clearance of apoptotic cells in vivo. J Exp Med 2000, 192:359-366

25. Ajuebor MN, Das AM, Virag L, Flower RJ, Szabo C, Perretti M: Role of resident peritoneal macrophages and mast cells in chemokine production and neutrophil migration in acute inflammation: evidence for an inhibitory loop involving endogenous IL-10. J Immunol 1999, 162: 1685-1691

26. Ditzel $\mathrm{HJ}$ : The K/BxN mouse: a model of human inflammatory arthritis. Trends Mol Med 2004, 10:40-45

27. Serhan CN, Brain SD, Buckley CD, Gilroy DW, Haslett C, O'Neill LA, Perretti M, Rossi AG, Wallace JL: Resolution of inflammation: state of the art, definitions and terms. FASEB J 2007, 21:325-332

28. Krishnamoorthy S, Recchiuti A, Chiang N, Yacoubian S, Lee $\mathrm{CH}$, Yang R, Petasis NA, Serhan CN: Resolvin D1 binds human phagocytes with evidence for proresolving receptors. Proc Natl Acad Sci U S A 2010, 107:1660-1665

29. Maaser C, Kannengiesser K, Specht C, Lugering A, Brzoska T, Luger TA, Domschke W, Kucharzik T: Crucial role of the melanocortin receptor MC1R in experimental colitis. Gut 2006, 55:1415-1422

30. Lee DJ, Biros DJ, Taylor AW: Injection of an $\alpha$-melanocyte stimulating hormone expression plasmid is effective in suppressing experimental autoimmune uveitis. Int Immunopharmacol 2009, 9:1079-1086

31. Brzoska T, Luger TA, Maaser C, Abels C, Bohm M: $\alpha$-Melanocytestimulating hormone and related tripeptides: biochemistry, antiinflammatory and protective effects in vitro and in vivo, and future perspectives for the treatment of immune-mediated inflammatory diseases. Endocr Rev 2008, 29:581-602

32. Ajuebor MN, Virag L, Flower RJ, Perretti M, Szabo C: Role of inducible nitric oxide synthase in the regulation of neutrophil migration in zymosan-induced inflammation. Immunology 1998, 95:625-630

33. Manna SK, Sarkar A, Sreenivasan Y: $\alpha$-Melanocyte-stimulating hormone down-regulates $\mathrm{CXC}$ receptors through activation of neutrophil elastase. Eur J Immunol 2006, 36:754-769

34. Schlesinger N: Overview of the management of acute gout and the role of adrenocorticotropic hormone. Drugs 2008, 68:407-415

35. Getting SJ, Kaneva M, Bhadresa Y, Renshaw D, Leoni G, Patel HB, Kerrigan PM, Locke IC: Melanocortin peptide therapy for the treatment of arthritic pathologies. ScientificWorldJournal 2009, 9:1394-1414

36. Martinon F, Petrilli V, Mayor A, Tardivel A, Tschopp J: Gout-associated uric acid crystals activate the NALP3 inflammasome. Nature 2006, 440:237-241

37. Terkeltaub R: Update on gout: new therapeutic strategies and options. Nat Rev Rheumatol 2010, 6:30-38

38. Wachira SJ, Guruswamy B, Uradu L, Hughes-Darden CA, Denaro FJ: Activation and endocytic internalization of melanocortin 3 receptor in neuronal cells. Ann N Y Acad Sci 2007, 1096:271-286

39. Yona S, Heinsbroek SE, Peiser L, Gordon S, Perretti M, Flower RJ: Impaired phagocytic mechanism in annexin 1 null macrophages. $\mathrm{Br} J$ Pharmacol 2006, 148:469-477

40. Serhan CN, Yang R, Martinod K, Kasuga K, Pillai PS, Porter TF, Oh SF, Spite M: Maresins: novel macrophage mediators with potent antiinflammatory and proresolving actions. J Exp Med 2009, 206:15-23

41. Underhill DM: Macrophage recognition of zymosan particles. J Endotoxin Res 2003, 9:176-180
42. Savill JS, Wyllie AH, Henson JE, Walport MJ, Henson PM, Haslett C: Macrophage phagocytosis of aging neutrophils in inflammation: programmed cell death in the neutrophil leads to its recognition by macrophages. J Clin Invest 1989, 83:865-875

43. Maderna P, Godson C: Phagocytosis of apoptotic cells and the resolution of inflammation. Biochim Biophys Acta 2003, 1639:141151

44. Fadok VA, Bratton DL, Konowal A, Freed PW, Westcott JY, Henson PM: Macrophages that have ingested apoptotic cells in vitro inhibit proinflammatory cytokine production through autocrine/paracrine mechanisms involving TGF- $\beta$, PGE2, and PAF. J Clin Invest 1998 101:890-898

45. Kim S, Elkon KB, Ma X: Transcriptional suppression of interleukin-12 gene expression following phagocytosis of apoptotic cells. Immunity 2004, 21:643-653

46. Byrne A, Reen DJ: Lipopolysaccharide induces rapid production of IL-10 by monocytes in the presence of apoptotic neutrophils. J Immunol 2002, 168:1968-1977

47. Liu Y, Cousin JM, Hughes J, Van Damme J, Seckl JR, Haslett C, Dransfield I, Savill J, Rossi AG: Glucocorticoids promote nonphlogistic phagocytosis of apoptotic leukocytes. J Immunol 1999, 162:3639_ 3646

48. Scannell M, Flanagan MB, deStefani A, Wynne KJ, Cagney G, Godson C, Maderna P: Annexin-1 and peptide derivatives are released by apoptotic cells and stimulate phagocytosis of apoptotic neutrophils by macrophages. J Immunol 2007, 178:4595-4605

49. Godson C, Mitchell S, Harvey K, Petasis NA, Hogg N, Brady HR: Cutting edge: lipoxins rapidly stimulate nonphlogistic phagocytosis of apoptotic neutrophils by monocyte-derived macrophages. J Immunol 2000, 164:1663-1667

50. Mioni C, Giuliani D, Cainazzo MM, Leone S, Bazzani C, Grieco P, Novellino E, Tomasi A, Bertolini A, Guarini S: Further evidence that melanocortins prevent myocardial reperfusion injury by activating melanocortin MC3 receptors. Eur J Pharmacol 2003, 477:227-234

51. Rossi AG, McCutcheon JC, Roy N, Chilvers ER, Haslett C, Dransfield I: Regulation of macrophage phagocytosis of apoptotic cells by CAMP. J Immunol 1998, 160:3562-3568

52. Frasch SC, Fernandez-Boyanapalli RF, Zemski Berry K, Leslie CC, Bonventre JV, Murphy RC, Henson PM, Bratton DL: Signaling via macrophage G2A enhances efferocytosis of dying neutrophils by augmentation of Rac activity. J Biol Chem 2011, 286:12108-12122.

53. Bystrom J, Evans I, Newson J, Stables M, Toor I, van Rooijen N, Crawford M, Colville-Nash P, Farrow S, Gilroy DW: Resolution-phase macrophages possess a unique inflammatory phenotype that is controlled by cAMP. Blood 2008, 112:4117-4127

54. Jones ST, Denton J, Holt PJ, Freemont AJ: Possible clearance of effete polymorphonuclear leucocytes from synovial fluid by cytophagocytic mononuclear cells: implications for pathogenesis and chronicity in inflammatory arthritis. Ann Rheum Dis 1993, $52: 121-126$

55. Kirkham PA, Spooner G, Rahman I, Rossi AG: Macrophage phagocytosis of apoptotic neutrophils is compromised by matrix proteins modified by cigarette smoke and lipid peroxidation products. Biochem Biophys Res Commun 2004, 318:32-37

56. Taylor AE, Finney-Hayward TK, Quint JK, Thomas CM, Tudhope SJ, Wedzicha JA, Barnes PJ, Donnelly LE: Defective macrophage phagocytosis of bacteria in COPD. Eur Respir J 2010, 35: 1039-1047

57. Vandivier RW, Richens TR, Horstmann SA, deCathelineau AM, Ghosh M, Reynolds SD, Xiao YQ, Riches DW, Plumb J, Vachon E, Downey GP, Henson PM: Dysfunctional cystic fibrosis transmembrane conductance regulator inhibits phagocytosis of apoptotic cells with proinflammatory consequences. Am J Physiol Lung Cell Mol Physiol 2009, 297:L677-L686 